Special issue of the 2nd International Conference on Computational and Experimental Science and Engineering (ICCESEN 2015)

\title{
Geochemical Characters of the Gabbroic Rocks in Ophiolite Sequences of North Hatta Area, United Arab Emirates
}

\author{
M. El Tokhi*, B. El Din Mahmoud Amin and H. Arman \\ United Arab Emirates University, College of Science, Department of Geology, Al-Ain, United Arab Emirates

\begin{abstract}
The ophiolite sequences of UAE, as a part of Oman ophiolite, represent both, mantle section and crustal section. The crustal part of the ophiolite sequences, consists of a layered series (cumulate peridotites and gabbros). This paper aims to overview geochemical character and some mechanical and physical features of the gabbroic rocks. The gabbros comprise troctolite, olivine gabbro, normal gabbro, gabbronorite, and uralitized gabbros. Geochemical features indicate that they are tholeiitic and are formed in an arc-related tectonic setting. On NMORB normalized pattern of gabbros, the HFS-elements ( $\mathrm{P}, \mathrm{Zr}, \mathrm{Sm}, \mathrm{Ti}$, and $\mathrm{Y}$ ) show a flat pattern parallel to NMORB. In contrast, the LIL-elements $(\mathrm{Rb}, \mathrm{Ba}, \mathrm{Th}, \mathrm{Sr}$ ) are relatively more enriched than NMORB. The enrichment of LIL-elements over the HFS-elements and the depletion of $\mathrm{Nb}$ relative to other HFS-elements suggest involvement of subduction component in the depleted mantle source, and suggest that these rocks were formed in a supra-subduction zone tectonic setting.
\end{abstract}

DOI: 10.12693/APhysPolA.130.17

PACS/topics: 91.62.Rt, 92.20.Ny

\section{Introduction}

Hatta area represents an ideal zone, showing the contact between the ophiolite rocks with the underlying melange complex. The tectonic events affecting the area are supposed to be the result of obduction of the ophiolitic suite on already formed sedimentary rocks of the Arabian continental margin. Structurally, the Hatta Zone is northwest-southwest trending, elongated window through the Semail ophiolite. The lithological assemblage and general structural relationship of the Hatta zone is similar to that of the Dibba zone. Hatta zone forms an equally chaotic appearance and is bounded to north and south by rocks of the Semail suite. A thrust contact can be inferred from the aerial photographs and from regional tectonic relationships, but in the field the thrust planes are difficult to locate owing to extensive areas of superficial deposits and later periods of folding and fracturing.

Wadi Hatta area covers about $280 \mathrm{~km}^{2}$ and represents a part of the Hatta Zone. This zone was interpreted as $50 \mathrm{~km}$ long left-lateral of the north Oman passive continental margin that was generated by right-lateral transform faulting during the spreading of Neo-Thyses Ocean [1]. The geology of south Wadi Hatta south area was studied in [2]. This area can be considered as an ideal zone exhibiting the contact between ophiolitic rocks with the underlying Hawasina basinal sediments.

The ophiolitic rocks in the studied area comprise mantle and crustal sequences. The mantle peridotite and crustal gabbros are the dominant rock types of the exposed Semail Ophiolite north of the Hatta Zone as mountains blocks or as fragments incorporated in

\footnotetext{
*corresponding author; e-mail: meltokhi@uaeu.ac.ae
}

melange mixture. This paper is only concentrated on the gabbroic rocks in northern part of Hatta area.

The main objective of this study is to identify the geochemical behavior and the tectonic setting of the gabbroic rocks and to study their mechanical, physical and petrographical properties, to help engineers to get a better knowledge of gabbroid rocks.

\section{General geology}

The studied area lies north of the Hatta Zone, between latitudes $24^{\circ} 48^{\prime}$ and $24^{\circ} 56^{\prime} \mathrm{N}$ and longitudes $55^{\circ} 58^{\prime}$ and $56^{\circ} 12^{\prime}$ E, Fig. 1. The rocks of Hatta area consist chiefly of

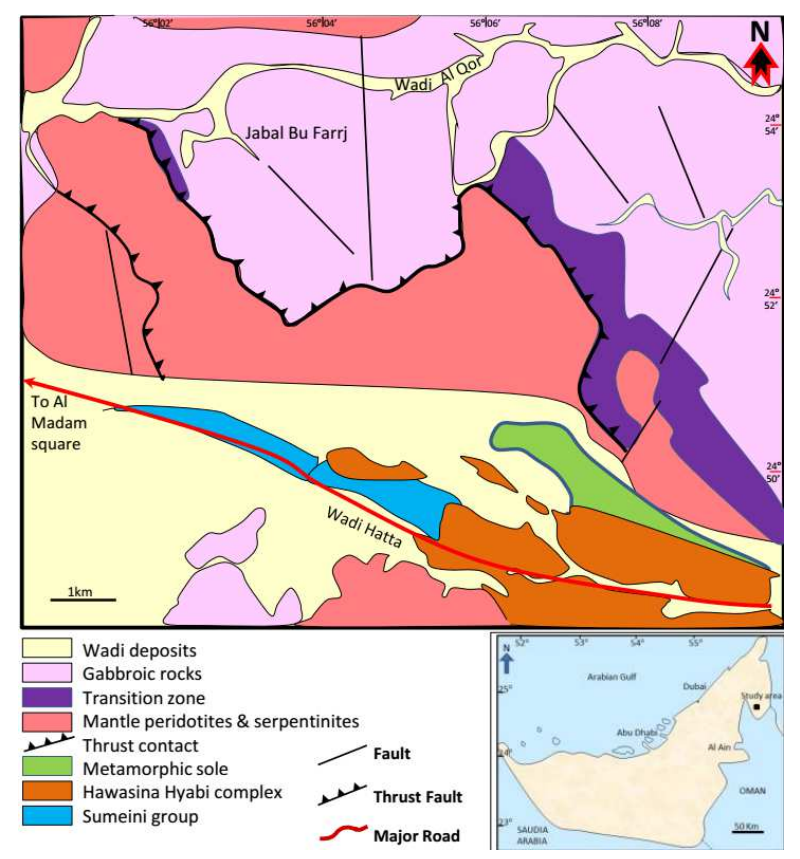

Fig. 1. Simplified geologic map of the studied area. 
mafic and ultramafic rocks which are considered as units of the ophiolitic succession according to the guide lines of the GSA Penrose conference [3].

Field observation has revealed that the rock units structurally exposed in the Hatta Zone below the Semail ophiolite, include platform slope carbonates (Sumeini Group), base of slope re-deposited sediments (Hamrat Dom Group), and more distal, deep-sea sediments, volcanic and metamorphic rocks of the ophiolite sole (Haybi Complex).

The ophiolitic rocks are found either as mountainous blocks or as fragments incorporated in the melange mixture. The metamorphic peridotites are encountered as fragmental blocks in the southwest part of the area and as mountainous blocks in the central east part, along the northern limb of Wadi Hatta. Gabbroic rocks are exposed as separate mountainous blocks in the northern part of the area. They show a variety of types from pyroxenites to trondjhemite. Primary rhythmic layering is well developed, where plagioclase-rich bands alternate with the pyroxene-rich bands.

\subsection{Mafic rocks}

The gabbroic rocks in Oman are divided into "lower gabbros", with marked modal layering, and "upper gabbros" directly underlying the sheeted dikes complex and include "isotropic gabbros" and diorite [4]. They also form the most varied rock assemblage in the Semail Ophiolite and have been classified in [5] into three main units from bottom to top: transition zone gabbros; layered gabbros; and high level hypabyssal-gabbroid rocks, respectively [6].

The gabbroic rocks in the studied area form rugged mountains and rest in a tectonic contact against the underlying mantle sequence. They occur as faulted blocks to the east and north of the studied area, being bounded to the NE and NW by thrust faults, which have emplaced them over the tectonized peridotite. The gabbros comprise troctolite, olivine gabbro, gabbronorite, and uralitized gabbros.

\section{Petrography}

Petrographic characteristic of the studied rocks is used in the interpretation of origin and genesis of the area. The classification of the mafic rocks in the studied area follows the nomenclature system from [7], as recommended by the IUGS Subcommission on the Systematics of Igneous Rocks.

The gabbroic rocks are made up primarily of four minerals: olivine (Ol.), clinopyroxene (Cpx.), orthopyroxene (Opx.) and plagioclase (Pl.), with substantial amount of hornblende (Hb), Fig. 2, [8]. On the basis of the lithology of the mantle-crust transition zone and crustal sequence, the gabbroic rocks in the studied area can be divided into the following types.

\subsection{Troctolite and olivine gabbro.}

The troctolite and olivine gabbros form one of the most common rock types in the layered gabbroic sequence

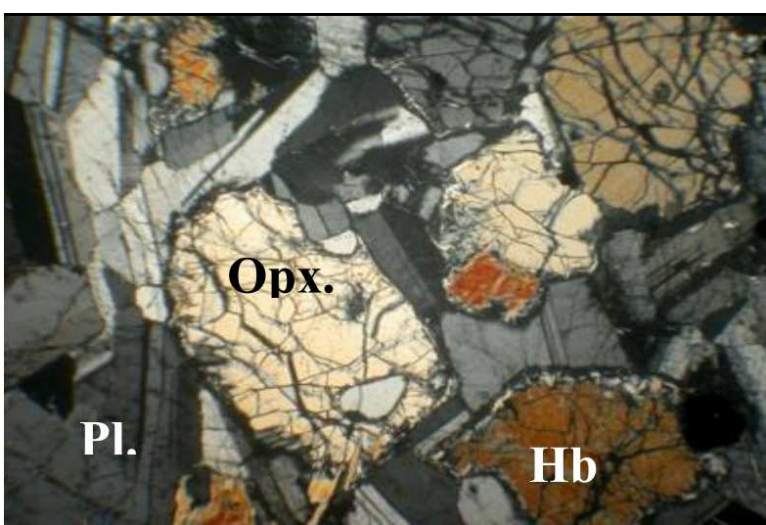

Fig. 2. Example of composition of gabbroic rock.

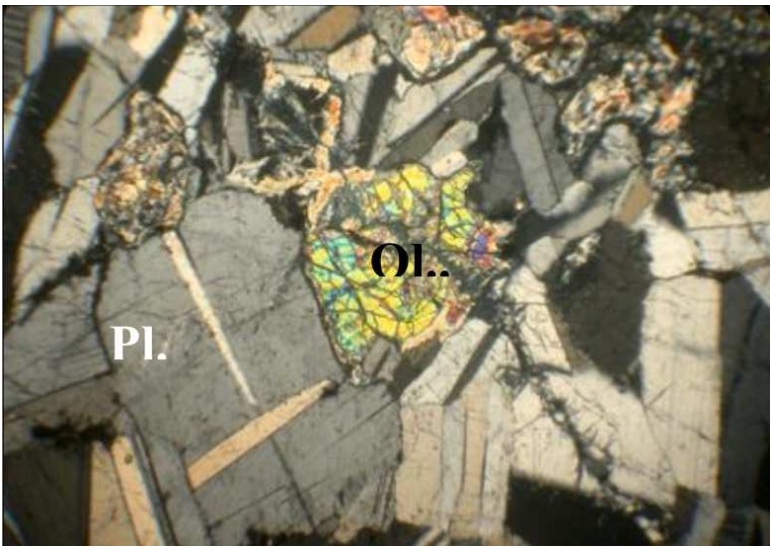

Fig. 3. Troctolite and olivine gabbro.

(Fig. 3). Troctolites consist mainly of plagioclase and olivine, while pyroxene represents less than $10 \%$ of the volume.

\subsection{Gabbronorite}

This rock is mainly composed of plagioclase, diopside and subordinate orthopyroxene and olivine. Plagioclase is an intercumulus phase found as subhedral to anhedral crystals, partly saussuritized and showing traces of deformational lamellae. Clinopyroxenes are partly altered to tremolite, chlorite and uralite (Fig. 4).

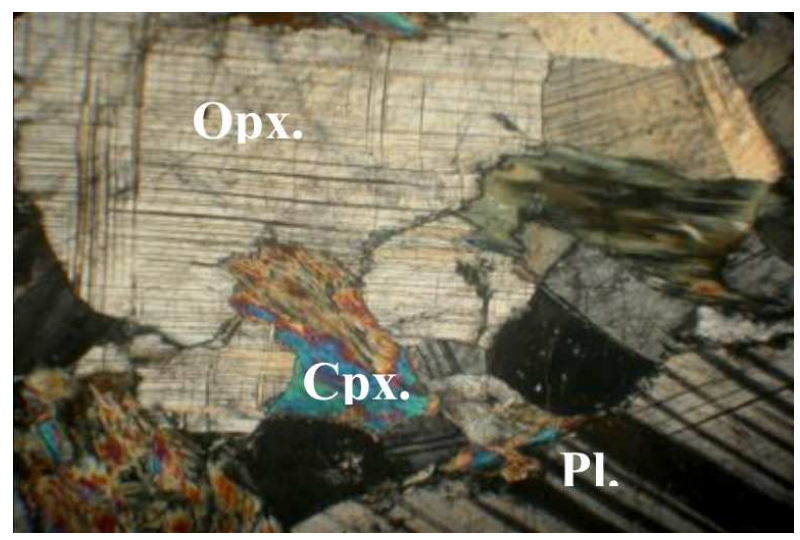

Fig. 4. Example of gabbronorite rock. 


\subsection{Normal gabbro}

Normal gabbro is medium to coarse-grained and is usually characterized by equigranular textures. It consists of plagioclase and clinopyroxene with minor amphibole and olivine. Clinopyroxene is more abundant and forms subhedral prismatic grains or irregular grains intergrown with plagioclase, Fig. 5.

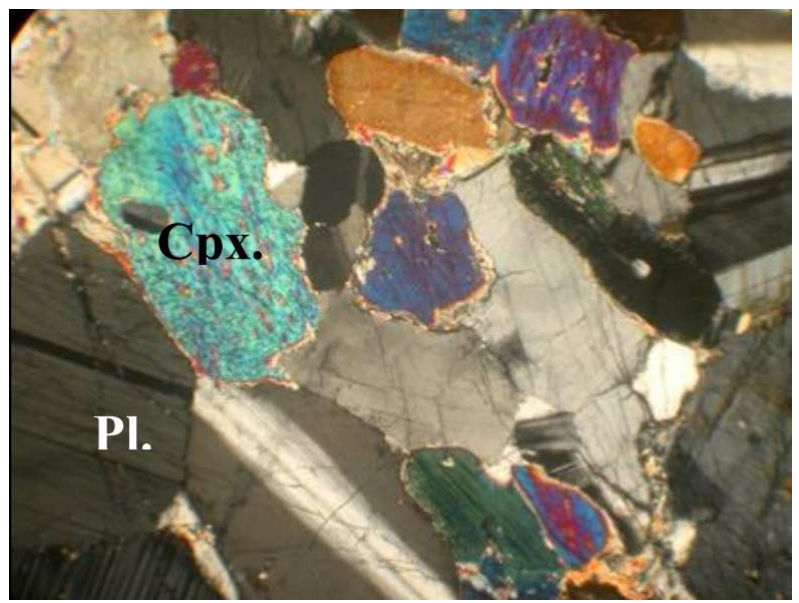

Fig. 5. Example of normal gabbro rock.

\subsection{Pegmatitic gabbro}

This rock is a very coarse-grained massive rock, consisting essentially of cumulate plagioclase and uralitized pyroxene, Fig. 6. Its crystals are quite elongated and show no zoning.

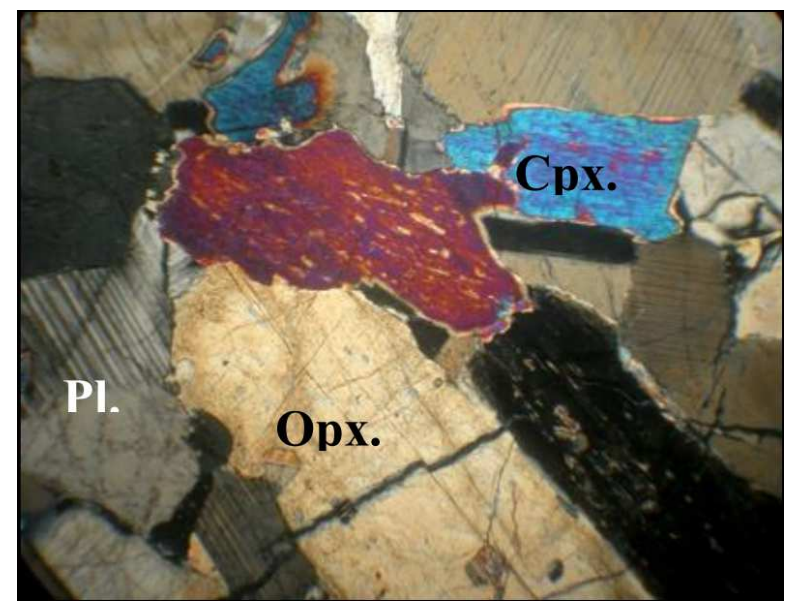

Fig. 6. Example of pegmatitic gabbro rock.

\subsection{Metagabbros}

Metagabbros are associated with the normal and olivine gabbros. They are mainly composed of plagioclase, uralitized pyroxene and some hornblende. The main accessory minerals are magnetite, apatite and epidote.

\section{Labratory studies}

\subsection{Sample preparation and testing}

Ten samples of gabbros were analyzed for major and trace elements and some of rare earth elements (REE). The samples were crushed in a jaw crusher. The weathered surfaces were removed and the fresh parts were powdered using a tungsten carbide mill to the size of $<200$ mesh. The chemical analysis was carried out using inductively coupled plasma-mass spectrometry (ICP-MS) at Geological Survey of Egypt.

\subsection{Classification}

The concentration of major, trace and some REE of all studied gabbros samples are reported in Table I. The Hatta gabbros are classified by plotting the total alkali versus $\mathrm{SiO}_{2}$ diagram, as in [9]. All samples in the plot appear in the related gabbro field, confirming their gabbroic character (Fig. 7). Most of the gabbro samples have very low content of total alkali and $\mathrm{SiO}_{2}$, which may be due to their cumulate nature or due to alteration.

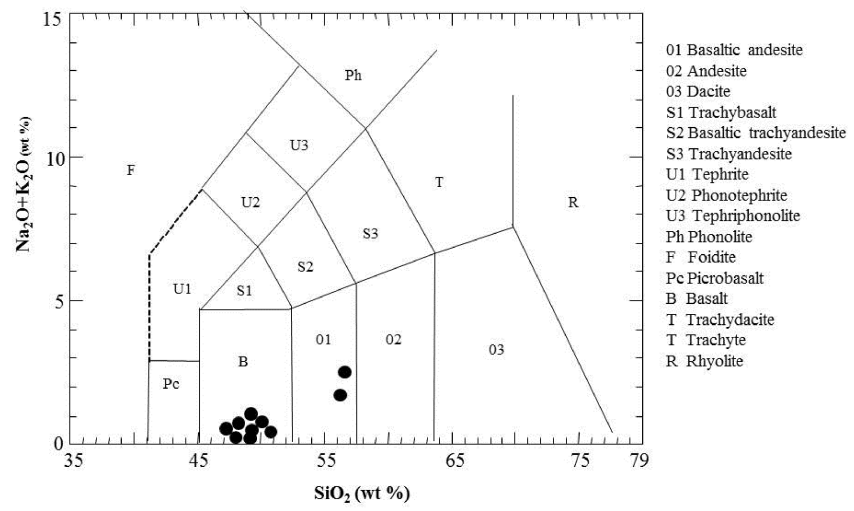

Fig. 7. Total alkali versus $\mathrm{SiO}_{2}$ diagram of the studied gabbroic rocks [9].

\subsection{Major elements characteristics}

Hatta gabbros have low concentrations (wt.\%) of $\mathrm{SiO}_{2}(47.68-56.72), \mathrm{TiO}_{2}(0.07-0.51), \mathrm{Na}_{2} \mathrm{O}+\mathrm{K}_{2} \mathrm{O}(0.02-$ 2.37), $\mathrm{P}_{2} \mathrm{O}_{5}(0.01-0.08)$ and wide ranges of $\mathrm{Al}_{2} \mathrm{O}_{3}(10.61-$ $20.81), \mathrm{Fe}_{2} \mathrm{O}_{3}^{t}$ (5.54-12.98), $\mathrm{MgO}(7.27-9.60)$ and $\mathrm{CaO}$ (8.30-17.87). The high concentration of $\mathrm{CaO}$ is due to alteration and the presence of small veinlets of calcite and epidote. The very low $\mathrm{Na}_{2} \mathrm{O}+\mathrm{K}_{2} \mathrm{O}$ contents can be explained by the cumulate nature of the rocks. This cumulate nature becomes more evident when the $\mathrm{SiO}_{2}$ and $\mathrm{MgO}$ are plotted against selected major elements as fractionation index (Fig. 8). In most of the plots the samples cluster together with only minor degree of scattering. The clustering of most of the samples in these plots can be interpreted using a model, that these gabbros are less affected by the fractionation and where they scattered, they show their cumulate nature. 
TABLE I

Major oxides and trace elements for W. Qor Gabbros.

\begin{tabular}{|c|c|c|c|c|c|c|c|c|c|c|}
\hline S.N & Q1 & Q2 & Q3 & Q4 & Q5 & Q6 & Q10 & Q11 & Q12 & Q13 \\
\hline $\mathrm{SiO}_{2}$ & 56.72 & 49.41 & 49.22 & 47.68 & 49.09 & 48.17 & 48.07 & 50.24 & 50.45 & 56.13 \\
\hline $\mathrm{TiO}_{2}$ & 0.47 & 0.43 & 0.25 & 0.07 & 0.36 & 0.31 & 0.08 & 0.25 & 0.51 & 0.45 \\
\hline $\mathrm{Al}_{2} \mathrm{O}_{3}$ & 12.09 & 12.77 & 10.61 & 20.81 & 14.12 & 12.96 & 19.25 & 14.27 & 13.00 & 11.87 \\
\hline $\mathrm{Fe}_{2} \mathrm{O}_{3}$ & 10.18 & 11.50 & 8.37 & 6.04 & 7.75 & 8.60 & 5.54 & 10.07 & 12.98 & 10.36 \\
\hline $\mathrm{MnO}$ & 0.18 & 0.18 & 0.20 & 0.11 & 0.14 & 0.14 & 0.12 & 0.17 & 0.21 & 0.18 \\
\hline $\mathrm{MgO}$ & 7.72 & 8.19 & 11.17 & 9.60 & 8.55 & 8.23 & 8.44 & 8.47 & 7.91 & 7.27 \\
\hline $\mathrm{CaO}$ & 8.30 & 13.61 & 16.14 & 13.62 & 17.87 & 18.06 & 17.86 & 14.86 & 12.16 & 9.61 \\
\hline $\mathrm{Na}_{2} \mathrm{O}$ & 2.26 & 0.73 & 0.32 & 0.23 & 0.82 & 0.80 & 0.01 & 0.24 & 0.08 & 1.77 \\
\hline $\mathrm{K}_{2} \mathrm{O}$ & 0.11 & 0.12 & 0.01 & 0.01 & 0.01 & 0.01 & 0.01 & $<0.01$ & $<0.01$ & 0.13 \\
\hline $\mathrm{P}_{2} \mathrm{O}_{5}$ & 0.08 & 0.06 & 0.01 & 0.01 & 0.01 & 0.06 & 0.01 & 0.02 & 0.02 & 0.05 \\
\hline LOI & 1.59 & 2.70 & 3.46 & 1.59 & 1.03 & 2.38 & 0.39 & 1.12 & 2.42 & 1.88 \\
\hline $\mathrm{Al}$ & 6.40 & 6.76 & 5.62 & 11.01 & 7.47 & 6.86 & 10.19 & 7.55 & 6.88 & 6.28 \\
\hline $\mathrm{Ti}$ & 0.28 & 0.26 & 0.15 & 0.04 & 0.22 & 0.19 & 0.05 & 0.15 & 0.31 & 0.27 \\
\hline $\mathrm{Mg}$ & 4.92 & 5.22 & 7.12 & 6.12 & 5.45 & 5.25 & 5.38 & 5.40 & 5.04 & 4.64 \\
\hline $\mathrm{Ca}$ & 5.93 & 9.73 & 11.54 & 9.73 & 12.77 & 12.91 & 12.76 & 10.62 & 8.69 & 6.87 \\
\hline $\mathrm{P}$ & 0.03 & 0.03 & 0.00 & 0.00 & 0.00 & 0.03 & 0.00 & 0.01 & 0.01 & 0.02 \\
\hline $\mathrm{K}$ & 0.09 & 0.10 & 0.01 & 0.01 & 0.01 & 0.01 & 0.00 & 0.00 & 0.00 & 0.00 \\
\hline $\mathrm{Na}$ & 1.68 & 0.54 & 0.24 & 0.17 & 0.61 & 0.59 & 0.01 & 0.18 & 0.06 & 1.31 \\
\hline $\mathrm{Si}$ & 35.28 & 30.73 & 30.61 & 29.65 & 30.53 & 29.96 & 29.90 & 31.25 & 31.38 & 34.91 \\
\hline $\mathrm{V}$ & 135.2 & 153.6 & 84.4 & 22.8 & 94.3 & 96.2 & 65.3 & 103.5 & 160.2 & 123.3 \\
\hline $\mathrm{Cr}$ & 502.7 & 85.4 & 910.3 & 87.2 & 230.7 & 310.1 & 104.5 & 200.4 & 300.6 & 490.3 \\
\hline $\mathrm{Ni}$ & 115.4 & 75.3 & 180.4 & 66.9 & 75.5 & 116.2 & 157.4 & 90.2 & 95.5 & 115.2 \\
\hline $\mathrm{Cu}$ & 20.7 & 24.5 & 66.7 & 15.4 & 16.4 & 45.5 & 60.7 & 23.9 & 55.6 & 25.5 \\
\hline $\mathrm{Zn}$ & 57.8 & 45.5 & 43.2 & 35.6 & 33.4 & 39.5 & 39.8 & 42.5 & 56.9 & 56.2 \\
\hline $\mathrm{Ga}$ & 14.5 & 13.9 & 14.4 & 15.6 & 14.6 & 14.2 & 14.4 & 14.8 & 14.2 & 14.8 \\
\hline $\mathrm{Ce}$ & 29.5 & 29.3 & 30.0 & 30.7 & 29.7 & 29.7 & 30.2 & 29.6 & 28.7 & 30.2 \\
\hline As & $<2.0$ & $<2.0$ & $<2.0$ & $<2.0$ & $<2.0$ & $<2.0$ & $<2.0$ & $<2.0$ & $<2.0$ & $<2.0$ \\
\hline $\mathrm{Y}$ & 15.4 & 13.8 & 12.3 & 12.5 & 13.5 & 11.7 & 11.7 & 11.7 & 11.4 & 14.5 \\
\hline $\mathrm{Rb}$ & 25.3 & 31.3 & 28.5 & 31.9 & 26.7 & 25.5 & 26.4 & 26.2 & 24.3 & 26.3 \\
\hline $\mathrm{Sr}$ & 135.4 & 143.6 & 153.5 & 150.2 & 164.3 & 151.2 & 110.5 & 108.6 & 109.8 & 133.2 \\
\hline $\mathrm{Zr}$ & 63.5 & 52.5 & 54.1 & 53.5 & 53.6 & 57.6 & 52.6 & 53.8 & 53.2 & 60.3 \\
\hline $\mathrm{Nb}$ & 6.5 & 4.5 & 4.7 & 5.3 & 4.2 & 4.1 & 4.3 & 4.2 & 4.0 & 4.5 \\
\hline $\mathrm{Sn}$ & $<2.0$ & $<2.0$ & $<2.0$ & $<2.0$ & $<2.0$ & $<2.0$ & $<2.0$ & $<2.0$ & $<2.0$ & $<2.0$ \\
\hline Hf & 2.6 & 2.5 & 2.7 & $<2.0$ & 2.6 & 2.5 & 2.5 & 2.6 & 2.5 & 2.6 \\
\hline $\mathrm{Ba}$ & 230.4 & 190.2 & 210.6 & 285.8 & 215.2 & 250.5 & 255.6 & 250.7 & 245.8 & 105.3 \\
\hline $\mathrm{La}$ & 16.2 & 16.0 & 16.5 & 17.0 & 16.4 & 16.3 & 16.6 & 16.2 & 15.7 & 16.6 \\
\hline $\mathrm{Yb}$ & $<2.0$ & $<2.0$ & 2.0 & $<2.0$ & $<2.0$ & $<2.0$ & $<2.0$ & $<2.0$ & $<2.0$ & $<2.0$ \\
\hline $\mathrm{Pb}$ & 16.4 & 15.9 & 16.8 & 17.4 & 16.6 & 16.4 & 16.7 & 16.6 & 15.9 & 17.0 \\
\hline Co & 35.2 & 34.5 & 28.2 & 25.3 & 25.6 & 27.3 & 23.4 & 30.4 & 35.9 & 32.4 \\
\hline $\mathrm{Th}$ & 4.2 & 4.1 & 4.3 & 4.5 & 4.3 & 4.2 & 4.3 & 4.3 & 4.0 & 4.4 \\
\hline
\end{tabular}

\subsection{Trace and rare earth elements characteristics}

Hatta gabbros have variable concentrations of both large-ion lithophile (LIL) elements (in ppm), such as $\mathrm{Ba}$ (105.3-285.8), Rb (24.3-31.9), Sr (108.6-164.3), Ce (28.7-30.2), and high field strength (HFS) elements like Zr (52.5-63.5), Y (11.4-15.4) and Nb (4.0-6.5). These rocks are variably altered and metamorphosed to greenschist facies. The alteration is obvious from the wider range of $\mathrm{CaO}(8.30-17.87)$ and LOI content (0.39-2.70). So it is expected that the LIL elements $(\mathrm{Rb}, \mathrm{K}, \mathrm{Ba}, \mathrm{Sr})$ have been remobilized to variable degree during these alteration processes $[10,11]$. Zr is plotted against the HFS elements (Nb, Y, Ti, P) in Fig. 9. These plots show a linear relationship with some degree of scatter, probably in rocks having cumulate phases. These trends show that all the gabbroic rocks are probably formed from a single parental magma through the process of fractional crystallization. It further confirms that the HFS elements are less-affected by secondary alteration, so the data for these elements will be reliable to use for the petrogenesis and tectonic setting of these rocks. 

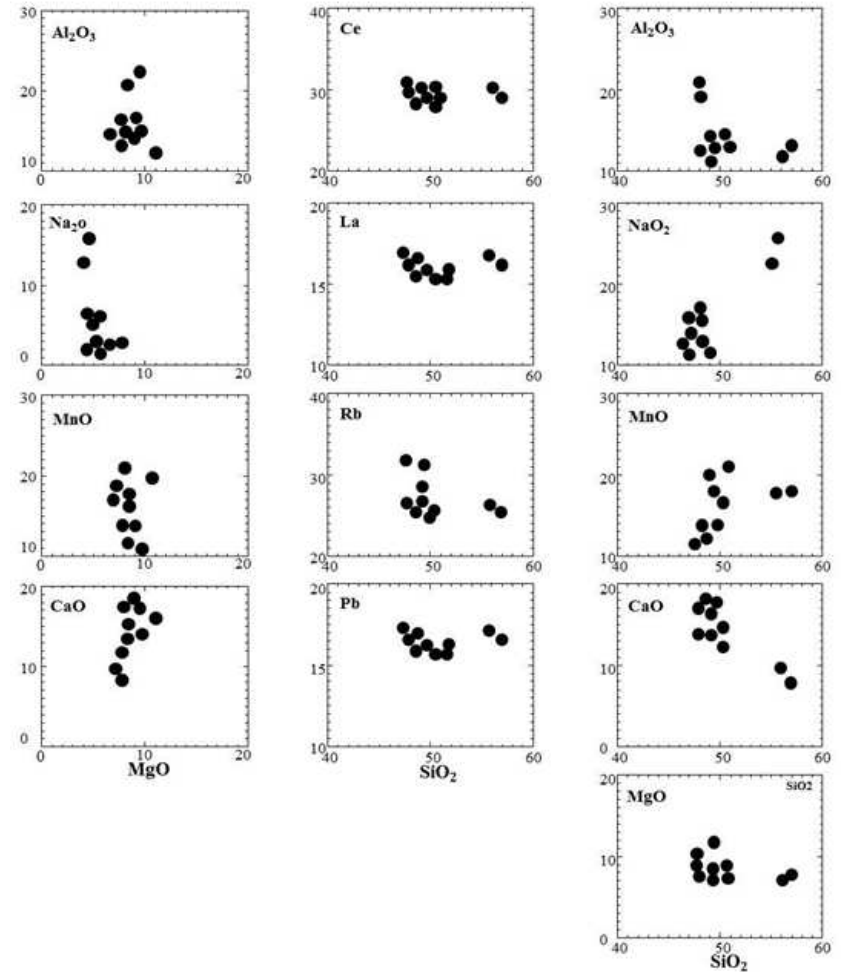

Fig. 8. Harker variation diagram of $\mathrm{SiO}_{2}$ and $\mathrm{MgO}$ vs. some major and trace elements contents of the Wadi $\mathrm{Al}$ Qor gabbros.
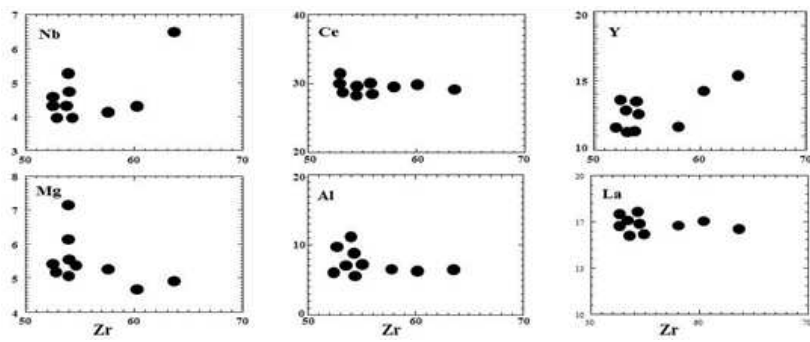

Fig. 9. Harker variation diagram of $\mathrm{Zr}$ versus some trace elements HFS contents of the Wadi Al Qor gabbros.

The trace and some REEs of Hatta gabbros are evaluated by plotting on multielement normalised diagram (Fig. 10). In the NMORB normalized pattern [12] of these gabbros the HFS-elements (P, Zr, Sm, Ti, and Y) show a semi flat pattern parallel to MORB. In contrast, the LIL-elements ( $\mathrm{Rb}, \mathrm{Ba}, \mathrm{Th}, \mathrm{Pb})$ are relatively more enriched than MORB. The enrichment in LIL elements may be due to the addition of a subduction component to NMORB source [13-15]. The ophiolitic gabbros of Massafi [16] show the same pattern of the studied gabbros.

\section{Discussion and conclusions}

Hatta gabbros include olivine gabbro, norite gabbro, normal gabbro and pegmatite gabbro. They show the characteristics of tholeiitic igneous rocks in AFM diagram

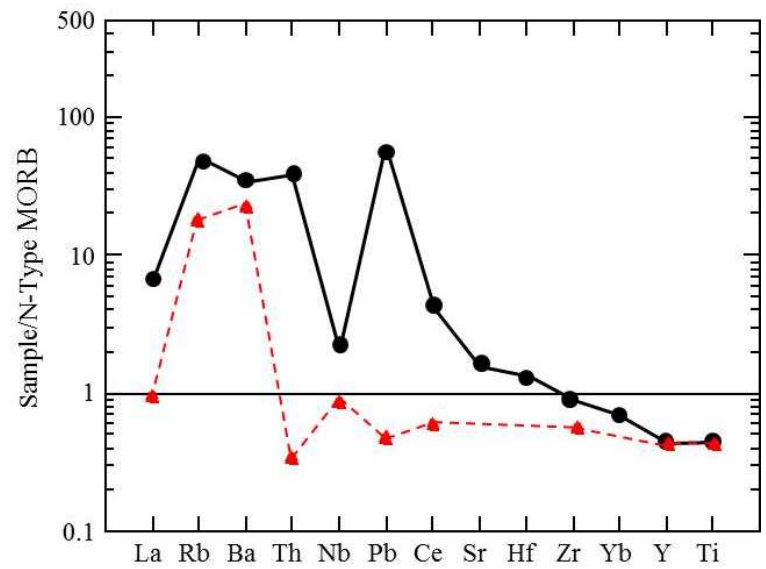

Fig. 10. N-MORB normalized pattern [12]. Solid line represents the studied gabbros and the dashed line represents the Massafi ophiolitic gabbros.

(Fig. 11a) [17] and their plot of $\mathrm{Y}$ against $\mathrm{Cr}$ is similar to that of tholeiitic rocks (Fig. 11b) [18]. The geochemical features of the major and trace elements show that the rocks have both cumulate and non-cumulate phases and that all three minerals; olivine, pyroxenes and plagioclases $(\mathrm{ol}+\mathrm{pyx}+\mathrm{pl})$ are involved in the fractionation process. This type of mineralization is typical of decompression setting over a subduction zone [14]. Several attributes of the gabbroic rocks of the Hatta area point to the tectonic setting of magma generation, responsible for their formation. The tectonic discrimination diagrams e.g. $\mathrm{Nb} / \mathrm{Th}$ versus $\mathrm{Y}$ (Fig. 11c) of [19], place these gabbros in the arc field. The relationship between $\mathrm{Cr}$ versus $\mathrm{Y}$ diagram (Fig. 11b) of [18] and the triangle $\mathrm{TiO}_{2}-\mathrm{K}_{2} \mathrm{O}-\mathrm{P}_{2} \mathrm{O}_{5}$ (Fig. 11d), classify the gabbros as both island arc tholeiite (IAT) and depleted mantle oceanic floor basalt (N-MORB) (the mantle from which MORB is produced must be already depleted in incompatible elements). Considering the diagram from [20], none of the samples from gabbros is found to plot in the field of either within plate basalt, enriched mid oceanic ridge basalt (EMORB) or the calc-alkaline basalt $(\mathrm{CAB})$. There is a possibility that these gabbros may have a transitional character between the IAT and NMORB and so, it is likely that these gabbros have formed by fractionation in a low pressure extensional environment directly over a subduction zone or in the supra-subduction zone. The transitional character of the Hatta gabbros from IAT and NMORB is also indicated by their normalized trace and REE diagrams (Fig. 10). In the NMORB normalized plot the HFS-elements ( $\mathrm{P}, \mathrm{Zr}, \mathrm{Sm}, \mathrm{Ti}$, and Y) show more or less flat pattern, depicting NMORB affinity. While the enrichment of the LIL-elements ( $\mathrm{Rb}, \mathrm{Ba}, \mathrm{Th}, \mathrm{Sr}$ ) along with depletion in $\mathrm{Nb}$, suggest addition of a subduction component to the depleted mantle source. The suprasubduction setting of the gabbroic rocks from Hatta gabbros is further confirmed when major element compositions are plotted on the AFM diagram of [21]. Most of the gabbro samples plot in the arc-related mafic cumulate 
field, whereas some samples plot in the arc-related noncumulate field (Fig. 11a). This implies that both the cumulate and non-cumulate gabbroic rocks have formed in a supra subduction zone tectonic setting.
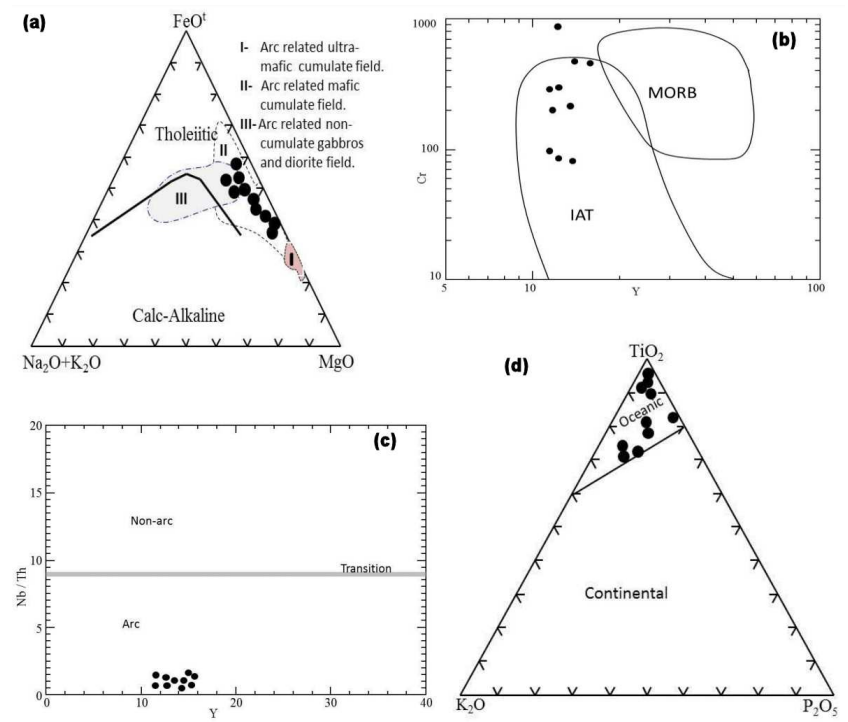

Fig. 11. (a) AFM diagram of gabbros, boundary line is that of [17]. I, II, III after [21]. (b) Cr versus Y diagram (IAT island arc tholeiites, MORB mid-ocean ridge basalts) [18]. (c) $\mathrm{Nb} / \mathrm{Th}-\mathrm{Y}$ plot [18]. (d) $\mathrm{TiO}_{2}-$ $\mathrm{K}_{2} \mathrm{O}_{-} \mathrm{P}_{2} \mathrm{O}_{5}$ diagram for the studied gabbros [18].

\section{Acknowledgments}

This work was financially supported by the Research Affairs at the UAE University under a contract no. COS/122/156. The authors grateful to the Department of Geology for encouragements and support which led to finalization of this research work.

\section{References}

[1] A.H.F. Robertson, A.E.S. Kemp, D.C. Rex, C.D. Blome, Geology. Soc., London, Special Publ. 49, 285 (1990).

[2] R.M. Bayoumi, M.T.S. Heikel, in: UAE 1st Int. Conf. Geol. Arab World, Cairo University 1992, p. 449.
[3] Anonymous, Penrose field conference on ophiolites: Geotimes, vol. 17, 1972, p. 24.

[4] P.B. Kelemen, G. Hirth, N. Shimizu, M. Spiegelman, H.J.B. Dick, Philos. Trans. R. Soc. A 355, 283 (1997).

[5] K.W. Glennie, M.G.A. Boeuf, M.W. Hughes Clarke, M. Moody-Stuart, W.F.H. Plan, B.M. Reinhardt, The geology of the Oman Mountains, Verhandelingen Koninklijke Nederland Geologisch Mijnbouwkundig Genootschap, 1974, p. 432.

[6] A.F. Osman, U.A.E. Journal Faulty Science 12, 1 (2002).

[7] L. Streckeisen, Monatshefte 1, 1 (1976).

[8] R.G. Coleman, Ophiolites, Springer-Verlag, BerlinHeidelberg 1977, p. 229.

[9] M.J. Le Bas, R.W. Le Maitre, A. Streckeisen, B. Zanetin, J. Petrol. 27, 745 (1986).

[10] S.E. Humphris, G. Thompson, Geochim. Cosmochim. Acta 42, 127 (1978).

[11] H. Staudigel, in: Treatise on geochemistry, Vol. 3, Eds. H.D. Holland, K.K. Turekian, Elsevier, Amsterdam 2003, p. 511; J.C. Gamble, Ph.D. Thesis, Geology, University of Illinois, Urbana 1971.

[12] S.S. Sun, W.F. McDonough, in: Magmatism in the ocean basins, Vol. 42, Eds. A.D. Saunders, M.J. Norry, Geological Society of London, London 1989, p. 313.

[13] D.A. Wood, Earth Planet. Sci. Lett. 50, 11 (1980).

[14] J.A. Pearce, S.J. Lippard, A. Roberts, Geology. Soc., London, Special Publ. 16, 77 (1984).

[15] A.D. Saunders, J. Tarney, in: Ocean Basalts, Blackie, Ed. P. Floyd, London 1991, p. 219.

[16] F.H. Mohamed, Geochemical and petrological characteristic the gabbroic rocks of the Massafi-Fujairah area, northern UAE, Internal report, UAE University, 2001.

[17] T.N. Irvine, W.R.A. Baragar, Can. J. Earth Sci. 8, 523 (1971).

[18] T.H. Pearce, B.E. Gorman, T.C. Birkett, Earth Planet. Sci. Lett. 24, 419 (1975).

[19] G.A. Jenner, G.R. Dunning, J. Malpas, M. Brown, T. Brace, Can. J. Earth Sci. 28, 1635 (1991).

[20] J.A. Pearce, J.R. Cann, Earth Planet. Sci. Lett. 19, 290 (1973).

[21] J.S. Beard, Geology 14, 848 (1986). 